\title{
Aspek Hukum Pidana dan Hukum Kontrak terkait Tindakan Akses Daftar Kontak Debitur oleh Perusahaan P2P Lending dalam Rangka Penagihan Utang
}

\author{
Rahel Octora \\ Fakultas Hukum Universitas Kristen Maranatha, Bandung \\ octorael@gmail.com
}

\begin{abstract}
Abstrak
Peningkatan kebutuhan masyarakat akan tersedianya dana membuat masyarakat mencari berbagai macam alternatif sumber dana, termasuk pembiayaan untuk memenuhi berbagai kebutuhan. Proses pengajuan pinjaman melalui lembaga keuangan bank yang mensyaratkan berbagai proses verifikasi sebelum permohonan pinjaman dapat dikabulkan, membuat sebagian masyarakat lebih memilih untuk meminjam dana melalui aplikasi / layanan penyaluran pinjaman yang beroperasi secara online. Proses yang dilalui tanpa tatap muka,berakibat pada tingginya risiko gagal bayar. Untuk mencegah hal tersebut, beberapa pihak penyelenggara pinjaman berbasis teknologi informasi menetapkan klausul bahwa pihak debitur setuju untuk memberikan ijin pada penyelenggara untuk mengakses data kontak yang terdapat pada ponsel milik debitur. Kemudian, dalam hal terjadi gagal bayar, pihak penyelenggara pinjaman melakukan penagihan kepada pihak ketiga (kontak debitur), dan penagihan tersebut seringkali dilakukan secara intimidatif. Penagihan yang bersifat intimidatif tersebut tentunya bersinggungan dengan peraturan hukum pidana yang berlaku di Indonesia. Penelitian ini dilakukan dengan metode yuridis normatif, di mana bahan-bahan yang digunakan adalah bahan hukum primer berupa peraturan perundang-undangan dan bahan hukum sekunder berupa berbagai literatur di bidang hukum. Hasil dari penelitian ini adalah bahwa pemberlakuan klausul di mana debitur mengijinkan perusahaan $P 2 P$ Lending melakukan akses kontak di Indonesia merupakan salah satu indikasi terjadinya undue influence atau penyalahgunaan keadaan. Negara harus memberikan batasan dengan memberlakukan ketentuan-ketentuan hukum yang bersifat memaksa. Tindakan penagihan secara intimidatif juga merupakan pelanggaran hukum pidana, khususnya UU ITE terkait dengan distribusi informasi elektronik yang bermuatan pengancaman. Perusahaan $P 2 P$ Lending sebagai sebuah korporasi seharusnya dapat dipertanggungjawabkan secara pidana.
\end{abstract}

Kata Kunci : P2P Lending, Daftar Kontak, Hukum Pidana, Hukum Kontrak

\begin{abstract}
Community needs of fund is now increased rapidly. It makes people look for various alternative sources of funds, to fulfill their needs. Banks may distribute such fund in the form of loan. The granting of loan from banks as creditors is written in a loan agreement document. The loan application process through a bank requires various verification processes before a loan application can be granted. This situation makes some people prefer to borrow funds through
\end{abstract}


Peer to Peer Lending Corporation, that operate through online platforms. The process is done without face to face verification process. It may cause a high risk of non-performing loan. To prevent the high risk of non-performing loan, information technology-based loan providers, commonly stipulate a clause that "the debtor agrees to give the permission to access the contact data contained on the debtor's cellphone." Then, in the event of a default, the loan provider will contact a third party (debtor contact) for debt collecting purposes, and the collection process oftentimes done with intimidation. Intimidating debt collecting, is certainly in violates criminal law regulations in Indonesia.This research was conducted using the normative juridical method, in which the materials used were primary legal materials in the form of legislation and secondary legal materials in the form of various literature in the field of law.The results of this study are: 1. the clause in online loan agreement, which state that the debtor allows P2P Lending companies to access contacts is an indication of undue influence or abuse of the situation. To overcome this problem, the state must impose administrative and criminal provisions. 2. Intimidating debt collecting is also a violation of criminal law, especially the Information and Electronic Transaction Law, related to the distribution of electronic information that contains threats. P2P Lending companies as a corporation should be criminally liable.

\section{Keywords: P2P Lending, Contact List, Criminal Law, Contract Law}

\section{Pendahuluan}

Perkembangan teknologi memberikan kemudahan bagi masyarakat untuk memenuhi kebutuhan hidupnya. Saat ini, berbagai transaksi di bidang ekonomi tidak lagi terbatas pada transaksi yang berlangsung secara tatap muka. Masyarakat membutuhkan dana untuk memenuhi kebutuhannya, dan terkadang anggota masyarakat dihadapkan pada situasi di mana kebutuhan atas dana terbilang tinggi dan kebutuhan tersebut tidak dapat dicukupi dengan dana yang dimiliki sehingga diperlukan dana dari sumber lain. Dana dapat diperoleh dari pinjaman.

Masyarakat dapat mengajukan pinjaman ke bank dalam bentuk kredit. Namun, mengingat demikian ketatnya persyaratan yang harus dipenuhi untuk memperoleh pinjaman, dan mengingat setiap bank terikat untuk menerapkan prinsip kehati-hatian, maka banyak orang mencari alternatif pembiayaan lain di luar jasa yang disediakan oleh bank.

Terkait dengan perkembangan teknologi, saat ini berkembang sarana peminjaman dana melalui platform / aplikasi online. Penyelenggara penyaluran dana pinjaman secara online, saat ini dikenal pula dengan istilah perusahaan penyelenggara Peer to Peer Lending $(P 2 P$ Lending). Melalui jasa yang disediakan oleh perusahaan $P 2 P$ Lending, calon debitur dapat memperoleh pinjaman dana secara instan tanpa melalui tahapan survey atau analisis kelayakan terlebih dahulu. Calon debitur hanya diminta untuk mengisi data-data secara elektronik, mengisi jumlah pinjaman yang akan diajukan, serta jangka waktu peminjaman. Kemudian, pada aplikasi tersebut akan dimunculkan perhitungan bunga, total pinjaman, dan jumlah yang harus dibayarkan. 
Setelah calon debitur menyatakan setuju terhadap syarat dan ketentuan yang ditetapkan oleh perusahaan $P 2 P$ Lending, dalam waktu singkat dana akan ditransfer ke rekening debitur.

Mengingat tahapan yang harus dilalui terbilang mudah dan sederhana, maka potensi terjadinya kredit macet / non-performing loan menjadi tinggi. Untuk mencegah hal tersebut, biasanya pihak perusahaan $P 2 P$ Lendingmemiliki ketentuan bahwa pihaknya dapat mengakses daftar nomor kontak yang terdapat pada ponsel debitur. Hal ini dapat diketahui ketika seorang calon debitur mulai meng-install suatu aplikasi, pada proses tersebut debitur diminta untuk menyetujui akses terhadap phone-book atau contact. Hal tersebut semula digunakan untuk melakukan verifikasi data debitur, namun dalam praktiknya, terjadi penyimpangan dalam pemanfaatan data daftar kontak tersebut. Jika debitur mengalami keterlambatan atau kegagalan pembayaran, maka pihak kreditur secara langsung menghubungi nama-nama yang berada di daftar kontak debitur tersebut, baik melalui telepon ataupun pesan singkat, dengan tujuan melakukan penagihan.

Tindakan seperti ini tentunya menimbulkan ketidaknyamanan yang dirasakan oleh rekan-rekan debitur yang sebenarnya sejak awal tidak pernah terlibat dalam transaksi utang piutang tersebut. Tindakan penagihan dengan cara menelepon atau mengirim pesan singkat tersebut seringkali juga disertai dengan ancaman seperti misalnya dalam pesan singkat ditulis: "mohon menghubungi Sdr.X, untuk melakukan pembayaran sejumlah x rupiah. Jika X tidak membayar, maka kami akan menghubungi anda terus, karena anda adalah kontak yang dicantumkan oleh $\mathrm{X}^{\prime}$.

Negara perlu mengatur dan mengawasi tindakan penagihan yang dilakukan oleh perusahaan pinjaman online, sehingga tindakan penagihan yang dilakukan secara intimidatif dan melanggar privasi pihak ketiga dapat dihentikan. Demikian pula negara harus secara tegas menerapkan ketentuan hukum pidana atas tindakan-tindakan pelanggaran privasi dan tindakan penagihan yang mengandung intimidasi tersebut.

\section{Permasalahan}

1 Apakah ketentuan dalam perjanjian elektronik antara perusahaan $P 2 P$ Lending dan debitur, yang menyatakan bahwa debitur memberikan hak bagi perusahaan P2P Lending untuk mengakses kontak debitur, merupakan klausul yang diperbolehkan oleh aturan hukum Indonesia?

2.Bagaimana sistem hukum pidana di Indonesia mengatur tindakan penagihan yang bersifat intimidatif terhadap pihak ketiga, yang dilakukan oleh perusahaan pinjaman online?

\section{Metode Penelitian}

Penelitian ini dilakukan dengan menggunakan metode penelitian yuridis normatif, yaitu bahwa pembahasan terhadap objek penelitian dikaji dalam tatanan normatif. Menurut Johnny Ibrahim, 
metode penelitian hukum normatif adalah suatu prosedur penelitian ilmiah untuk menemukan kebenaran berdasarkan logika keilmuan hukum dari sisi normatifnya. ${ }^{1}$ Metode yuridis normatif menunjuk pada metode penelitian dengan menganalisis data dan menghubungkannya dengan aturan hukum yang berlaku. ${ }^{2}$ Penelitian ini bersifat deskriptif analitis yaitu penelitian untuk memecahkan masalah, yang ada pada masa sekarang (masalah aktual), dengan mengumpulkan data, menyusun, mengklasifikasikan, dan menginterpretasi. ${ }^{3}$

Pendekatan yang digunakan dalam penelitian ini adalah pendekatan perundang-undangan dengan menelaah peraturan-perundang-undangan terkait dengan topik yang dibahas dan pendekatan konseptual dengan mengkaji makna dari konsep-konsep terkait dengan topik yang dibahas. Bahan hukum primer yang digunakan dalam penelitian ini adalah:

1. Kitab undang-undang Hukum Perdata

2. Undang-undang Nomor 8 tahun 1999 tentang Perlindungan Konsumen

3. Undang-undang Nomor 11 tahun 2008 sebagaimana diubah dengan Undang-undang Nomor 19 tahun 2016 tentang Informasi dan Transaksi Elektronik

4. Peraturan Otoritas Jasa Keuangan Nomor 77 /POJK.01/2016 tentang Layanan Pinjam Meminjam Uang Berbasis Teknologi Informasi

Demikian pula penelitian ini menggunakan bahan hukum sekunder berupa literatur dan jurnal hukum.

\section{Pembahasan}

Penggunaan jasa peminjaman dana melalui aplikasi online, sudah marak digunakan di Indonesia. Perusahaan Jasa Keuangan berbasiskan teknologi, atau sering diistilahkan dengan Perusahaan Financial Technology (Fintech), semakin mudah dijumpai. Masyarakat dapat menemukan keberadaan perusahaan fintech tersebut hanya dengan mencari dan mengunduhnya melalui smartphone. Setelah aplikasi tersebut ter-instal di dalam ponsel, setiap orang dapat langsung melakukan transaksi peminjaman dana. Selain melalui aplikasi yang ter-install dalam ponsel, kegiatan penyaluran dana pinjaman secara online juga dapat ditemukan di berbagai website, bahkan ada perusahaan fintech yang menawarkan pinjaman melalui pesan singkat (sms).

Masyarakat yang membutuhkan dana, biasanya tertarik dengan proses pencairan dana yang tepat. Untuk menjawab kebutuhan tersebut, saat ini banyak berkembang perusahan Fintech yang bersifat ilegal. Sebuah perusahaan jasa fintech dapat dikatakan ilegal jika tidak terdaftar di Otoritas Jasa Keuangan. Berdasarkan data yang diperoleh dari Otoritas Jasa Keuangan yang dipublikasikan pada tanggal 3 Desember 2019, dinyatakan bahwa Satuan Tugas Penanganan

\footnotetext{
${ }^{1}$ Johnny Ibrahim.Teori dan Metodologi Penelitian Hukum Normatif. Malang: Bayumedia Publishing, (2006),hlm.57

${ }^{2}$ Ronny Hanitijo Soemitro, Metodologi Penelitian Hukum, Jakarta:Ghalia Indonesia,(1982), hlm. 10.

${ }^{3}$ Soenaryo, Metode Riset I, Surakarta: Universitas Sebelas Maret, (1985), hlm. 8. 
Dugaan Tindakan Melawan Hukum di Bidang Penghimpunan Dana Masyarakat dan Pengelolaan Investasi atau Satgas Waspada Investasi, menemukan 125 entitas ang melakukan kegiatan fintech peer-to-peer lending ilegal yang tidak terdaftar di OJK. Sebelumnya, pada 7 Oktober 2019, Satgas Waspada Investasi telah menindak 133 entitas fintech peer-to-peer lending ilegal, sehingga total entitas fintech peer-to-peer lending ilegal yang ditangani Satgas Waspada Investasi sampai dengan November 2019 sebanyak 1.494 entitas dengan total entitas fintech peer-to-peer lending ilegal yang sudah ditindak oleh Satgas Waspada Investasi sejak tahun 2018 hingga November 2019 sebanyak 1.898 entitas. $^{4}$

Sampai saat ini, peraturan yang berlaku di Indonesia terkait dengan kegiatan penyaluran pinjaman dana secara online adalah Peraturan Otoritas Jasa Keuangan Nomor 77 /POJK.01/2016 Tentang Layanan Pinjam Meminjam Uang Berbasis Teknologi Informasi. Dalam Pasal 7 peraturan tersebut dinyatakan bahwa Penyelenggara wajib mengajukan pendaftaran dan perizinan kepada OJK.

Masyarakat seringkali tidak memperhatikan dengan cermat perihal legalitas usaha penyelenggara layanan peminjaman dana tersebut. Masyarakat seringkali hanya terfokus pada bagaimana mereka dapat memperoleh pinjaman secara cepat, walaupun kemudian mereka harus mengembalikan pinjamannya dalam jangka waktu tertentu disertai beban bunga yang relatif tinggi.

Sebagai simulasi, salah satu aplikasi peminjaman dana yang legal dan terdaftar di OJK menawarkan limit maksimum peminjaman sebesar Rp.3.000.000, (tiga juta rupiah), dan dalam 30 hari, debitur harus mengembalikan dana sejumlah Rp.3.700.000, (tiga juta tujuh ratus ribu rupiah). Artinya terdapat selisih sebesar hampir 24 persen dari pokok pinjaman. ${ }^{5} \mathrm{Hal}$ tersebut sesuai dengan aturan yang ditetapkan oleh Kode Etik Asosiasi Fintech Pendanaan Bersama Indonesia (AFPI), yang menyatakan bahwa: Bunga maksimal sebesar 0,8\% per hari dan akumulasi denda maksimal $100 \%$ dari nilai pokok. Besaran tersebut relatif tinggi jika dibandingkan dengan suku bunga yang ditetapkan dalam praktik perkreditan yang lazim di lingkungan perbankan.

Jika pinjaman telah disetujui, maka diwajibkan untuk membayar biaya layanan yang besarnya sekitar 3\%-5\% dari nilai pinjaman. Itu berarti jika peminjam mendapatkan persetujuan pinjaman sebesar Rp10 juta, maka uang yang bisa didapatkan hanya akan ada dikisaran Rp 9,5 juta sampai

\footnotetext{
${ }^{4}$ https://www.ojk.go.id/id/berita-dan-kegiatan/siaran-pers/Pages/Satgas-Waspada-Investasi-Temukan-lagi-125Fintech-Peer-To-Peer-Lending-Ilegal.aspx diakses tanggal 20 Februari 2020, pukul 13.00 WIB.

${ }^{5}$ Simulasi dalam aplikasi www.uangteman.com, diakses tanggal 21 Februari 2020, pukul 10.00 WIB.
} 
Rp9,7 juta. Besarnya biaya layanan berbeda-beda tergantung dari perusahaan aplikasi mana yang pergunakan. ${ }^{6}$

Sementara itu, perusahaan keuangan digital (financial technology/fintech) online ilegal mematok bunga pinjaman online lebih dari $1,5 \%$ per hari, dan tidak menerapkan batas pemberian denda yang artinya bisa sebesar-besarnya. ${ }^{7}$

\section{Pemberlakuan Klausul Pengaksesan Daftar Kontak oleh Perusahaan P2P Lending}

Berdasarkan Peraturan Otoritas Jasa Keuangan Nomor 77 /POJK.01/2016 Tentang Layanan Pinjam Meminjam Uang Berbasis Teknologi Informasi, dinyatakan bahwa ada tiga pihak yang terlibat dalam proses transaksi penyaluran pinjaman secara online, pihak-pihak yang dimaksud adalah :

1. Penyelenggara Layanan Pinjam Meminjam Uang Berbasis Teknologi Informasi: yaitu pihak yang menyediakan, mengelola, dan mengoperasikan Layanan Pinjam Meminjam Uang Berbasis Teknologi Informasi.

2. Penerima Pinjaman yaitu pihak debitur

3. Pemberi Pinjaman adalah orang, badan hukum, dan/atau badan usaha yang mempunyai piutang karena perjanjian Layanan Pinjam Meminjam Uang Berbasis Teknologi Informasi.

Dalam tulisan ini, penulis akan memfokuskan pada hubungan hukum yang terjadi antara Penyelenggara Layanan dengan Penerima Pinjaman. Hubungan kedua belah pihak tersebut merupakan hubungan dalam bidang hukum perdata, yaitu hubungan hukum yang terjadi karena perjanjian.

Adapun definisi dari perikatan adalah hubungan antara dua orang atau dua pihak berdasarkan mana pihak yang satu berhak menuntut sesuatu hal dari pihak yang laindan pihak yang lainnya berkewajiban untuk memenuhi prestasi tersebut ${ }^{8}$.Dalam transaksi tersebut, muncul hak dan kewajiban utama pada masing-masing pihak sebagai berikut:

Pihak kreditur :

1. Wajib memberikan pinjaman

2. Berhak mendapat pengembalian pinjaman beserta bunganya secara tepat waktu dan jumlah sesuai dengan yang diperjanjikan

Pihak debitur :

\footnotetext{
${ }^{6}$ Istiqamah, Analisis Pinjaman Online Oleh Fintech Dalam Kajian Hukum Perdata, Jurisprudentie, Jurnal Hukum UIN Allaudin, Volume 6 Nomor 2 Desember 2019, hlm 303.

${ }^{7}$ https://www.cermati.com/artikel/cara-lapor-polisi-bila-diteror-dan-diancam-pinjaman-online, diakses tanggal 21 Februari 2020, pukul 10.00 WIB.

${ }^{8}$ Hardijan Rusli, Hukum Perjanjian Indonesia dan Common Law, Jakarta, Pustaka Sinar Harapan, (1996), hlm. 26
} 
1. Berhak mendapatkan pinjaman

2. Wajib untuk mengembalikan pinjaman beserta jumlah pada waktu yang sudah diperjanjikan

Para pihak, dalam transaksi ini akan tunduk dan terikat pada syarat dan ketentuan yang ditetapkan secara sepihak oleh pelaku usaha (dalam hal ini perusahaan P2P Lending). Pelaku Usaha menetapkan syarat dan ketentuan yang bersifat baku, dan tidak dapat dinegosiasikan atau ditawar oleh pihak debitor. Di dalam sistem hukum Indonesia, pengaturan tentang klausula baku hanya terdapat dalam Pasal 18 Undang-undang Nomor 8 tahun 1999 tentang Perlindungan Konsumen.

Menurut Abdul Kadir Muhammad, perjanjian baku dialih bahasakan dari istilah asing yakni 'standaard contract'. Dimana baku atau standar memiliki arti sebagai tolak ukur, yakni pedoman atau patokan bagi konsumen dalam mengadakan hubungan hukum dengan pihak pengusaha. Dalam hal ini, yang dibakukan adalah model, rumusan dan ukuran. Artinya, tidak dapat diganti atau diubah lagi, karena produsen telah membuat atau mencetaknya dalam bentuk blanko tetap berupa naskah perjanjian lengkap dengan syarat- syarat perjanjian dan syarat- syarat baku yang wajib dipenuhi konsumen. ${ }^{9}$

Keberadaan klausul yang menyatakan bahwa pihak penyedia jasa berhak mengakses kontak, memang belum diatur secara eksplisit. Tidak ada ketentuan di dalam UU Perlindungan Konsumen yang menyatakan bahwa pelaku usaha dilarang memberlakukan jenis klausula tersebut. Dalam Pasal 18 UUPK, klausula baku yang dilarang misalnya tindakan sepihak dari pelaku usaha untuk menyatakan pemberian kuasa dari konsumen kepada pelaku usaha baik secara langsung maupun tidak langsung untuk melakukan segala tindakan sepihak yang berkaitan dengan barang yang dibeli oleh konsumen secara angsuran (Pasal 18 ayat 1 butir d). Dalam kasus pemberlakuan klausul akses kontak secara sepihak, pasal ini tidak sesuai karena pasal tersebut secara eksplisit mengatur transaksi dengan objek barang yang dibeli secara angsuran. Selain itu, Pasal 18 ayat (2) UUPK melarang pelaku usaha mencantumkan klausula baku yang letak atau bentuknya sulit terlihat atau tidak dapat dibaca secara jelas, atau yang pengungkapannya sulit dimengerti. Klausula akses kontak biasanya sudah dirumuskan secara jelas, dan pihak debitur harus menyetujuinya. Hal ini di dalam hukum perlindungan konsumen, dikualifikasikan sebagai tindakan penyalahgunaan keadaan (undue influence).

Saat ini, keberadaan kontrak baku merupakan hal yang biasa dijumpai dalam transaksi bisnis di berbagai bidang. Kontrak baku sering disebut pula sebagai kontrak dengan model take it or leave it. Artinya, konsumen sudah tidak memiliki kesempatan untuk menegosiasikan isi kontrak. Dalam pembuatan suatu kontrak, seharusnya diperhatikan prinsip keseketikaan (contemporaneous) dan dan prinsip tidak menyalahgunakan keadaan (undue influence).

\footnotetext{
${ }^{9}$ Lina Jamilah, Asas kebebasan Berkontrak Dalam Perjanjian Standar Baku, Syiar Hukum Vol 14, No.1, (2012), hlm. 13.
} 
Prinsip contemporaneousmerupakan suatu prinsip yang menyatakan bahwa para pihak dalam sebuah kontrak harus telah mengetahui dan memahami ketentuan dan persyaratan dalam kontrak, sebelum atau setidak- tidaknya pada saat kontrak ditutup oleh para pihak. Dalam praktik, kontrak baku digunakan untuk transaksi yang bersifat cepat dan massal, sehingga seringkali dalam kenyataannya, pihak konsumen tidak sempat membaca secara detil isi kontrak sebelum menandatanganinya. Isi klausula baku dalam kontrak baku pada umumnya hanya diketahui dan dipahami oleh pihak pembuat kontrak/ pelaku usaha. Kondisi tersebut menunjukkan bahwa perjanjian baku jelas melanggar atau bertentangan dengan prinsip contemporaneous. Selain itu, perjanjian baku pada umumnya memanfaatkan undue influence yaitu keadaan (kelemahan, keraguan, atau keadaan tertekan) pihak penutup kontrak, sehingga perilaku atau keputusan pihak tersebut berubah secara tidak bebas demi keuntungan pihak pembuat kontrak. Adapun menurut Johannes Gunawan (2003), indikasi undue influence dalam perjanjian baku, antara lain: 1. isi kontrak baku tidak masuk akal, tidak patut, bertentangan dengan kemanusiaan (unfair contract terms); 2. pihak penutup kontrak baku dalam keadaan tertekan; 3. pihak penutup kontrak baku tidak memiliki pilihan lain, kecuali menerima isi kontrak baku walaupun dirasakan memberatkan; 4. hak dan kewajiban para pihak tidak seimbang. ${ }^{10}$

Beberapa contoh klausula dalam syarat dan ketentuan peminjaman dana, yang menyatakan bahwa debitor setuju untuk mengizinkan perusahaan P2P lending mengakses kontaknya, misalnya berbunyi sebagai berikut:

"Penagihan melalui telepon kepada keluarga, teman atau pihak lain yang terkait dengan Peminjam yang nomor teleponnya tercantum sebagai "Nomor Darurat" atau sejenisnya yang diberikan Peminjam saat pengajuan aplikasi permohonan perolehan pinjaman kepada RupiahPlus ("Permohonan Meminjam Uang"), jika:

a) Peminjam terus menunggak utang dan tidak dapat dihubungi atau sulit dihubungi melalui nomor telepon selular yang dicantumkannya pada saat pengajuan Permohonan Meminjam Uang;

b) Peminjam terus menunggak utang dan tidak diketahui keberadaannya untuk dilakukan penagihan langsung meskipun telah diupayakan kunjungan atau komunikasi langsung kepada Peminjam tersebut;

c) Peminjam terus menunggak utang dan tidak beritikad baik untuk berkomunikasi dengan RupiahPlus terkait penagihan utang; dan/atau

\footnotetext{
${ }^{10}$ Sukarmi, Cyber Law: Kontrak Elektronik dalam Bayang-Bayang Pelaku Usaha, Bandung, Pustaka Sutra, (2008), hlm, 129
} 
d) Peminjam terus menunggak utang dan tidak merespon dengan baik upaya penagihan RupiahPlus."

Klausul yang menetapkan bahwa debitur menyetujui tindakan akses kontak oleh perusahaan P2P Lending merupakan salah satu bentuk penyalahgunaan keadaan (undue influence). Di Indonesia, syarat keabsahan suatu kontrak adalah dipenuhinya Pasal 1320 KUH Perdata, yaitu syarat kesepakatan, kecakapan, adanya suatu hal tertentu, dan adanya kausa yang halal. Suatu kesepakatan tidak boleh disertai adanya paksaan, kekhilafan dan / atau penipuan. Ajaran penyalahgunaan keadaan adalah menyangkut perwujudan asas kebebasan berkontrak, karena hal itu menyangkut penyalahgunaan untuk mengganggu adanya kebebasan kehendak untuk mengadakan persetujuannya. ${ }^{11}$

Pengaksesan daftar kontak tersebut merupakan salah satu contoh pelanggaran terhadap perlindungan data pribadi. Wahyudi Djafar dan Asep Komarudin mengemukakan sejumlah kasus yang mencuat, terutama yang memiliki keterkaitan dengan kebocoran data pribadi seseorang dan bermuara kepada aksi penipuan atau tindak kriminal pornografi, menguatkan wacana pentingnya pembuatan aturan hukum untuk melindungi data pribadi. Perlindungan data pribadi berhubungan dengan konsep privasi. Konsep privasi sendiri adalah gagasan untuk menjaga integritas dan martabat pribadi. $^{12}$

Penagihan kepada pihak ketiga yang sebenarnya tidak terlibat di dalam perjanjian peminjaman dana juga merupakan pelanggaran terhadap konsep privasi konsumen sehingga diperlukan pengaturan yang jelas terkait dengan hal ini.

Dalam perkembangan kontrak baku saat ini, perlindungan bagi pihak konsumen tidak dapat sepenuhnya diserahkan kepada kesepakatan para pihak yang dituangkan dalam isi kontrak. Dengan demikian, dalam praktik transaksi antara perusahaan P2P Lending dengan konsumen, negara perlu memberikan aturan-aturan yang memberikan batasan bagi tindakan pelaku usaha. Demikian Pula Agus Yudha Hernoko menyatakan: "Di dalam konkretonya Hukum Perdata khususnya hukum kontrak mencari bentuk baru untuk memenuhi tuntutan itu antara lain melalui campur tangan pemerintah, sehingga materi-materi yang menyangkut kepentingan umum akan mendapat perlindungan hukum, yaitu dengan memperbanyak peraturan-peraturan yang sifatnya memaksa (dwingen recht) dalam upaya melindungi pihak yang lemah. ${ }^{13}$ Dalam hal ini, penulis

\footnotetext{
11 Fatmah Paparang, Misbruik Van Omstandigheden Dalam Perkembangan Hukum Kontrak , Jurnal Hukum Unsrat, Vol.22/No.6/Juli /2016, hlm. 57.

${ }^{12}$ Erna Priliasari, Pentingnya Perlindungan Data Pribadi Dalam Transaksi Pinjaman Online (The Urgency Of Personal Protection In Peer To Peer Lending), Majalah Hukum Nasional, Nomor 2 tahun 2019, hlm. 21.

${ }^{13}$ Agus Yudha Hernoko, Hukum Perjanjian Asas Proporsionalitas Dalam Kontrak Komersial, Jakarta: Kencana Prenadamedia Group.,(2009), hlm.108.
}

\section{Recitol Review Vol. 2 No.2 Tahun 2020. E-ISSN: 2623-2928}


berpendapat, terdapat aspek hukum lain di luar aspek hukum kontrak yang harus diperhatikan dalam transaksi ini, yaitu hukum administratif dan hukum pidana.

Aturan hukum memaksa yang terkait dengan tindakan akses daftar kontak, masih menitikberatkan pada penegakan sanksi bidang administratif. Aturan tersebut dapat dilihat pada Pasal 26 ayat (1) Undang-undang No. 19 Tahun 2016 Tentang Perubahan Atas UndangUndang Nomor 11 Tahun 2008 Tentang Informasi Dan Transaksi Elektronik, yang menyatakan bahwa:Kecuali ditentukan lain oleh peraturan perundang-undangan, penggunaan setiap informasi melalui media elektronik yang menyangkut data pribadi seseorang harus dilakukan atas persetujuan Orang yang bersangkutan.

Tindakan pengaksesan daftar kontak yang kemudian ditindaklanjuti dengan tindakan pelaku usaha untuk menghubungi pihak ketiga dalam rangka penagihan, tenntunya melanggar ketentuan tersebut, karena pihak ketiga tidak pernah menyetujui penggunaan data pribadinya untuk tujuan tersebut.

Selain itu dalam Pasal 26 huruf a POJK Nomor 77 /POJK.01/2016 dinyatakan bahwa penyelenggara wajib "menjaga kerahasiaan, keutuhan, dan ketersediaan data pribadi, data transaksi, dan data keuangan yang dikelolanya sejak data diperoleh hingga data tersebut dimusnahkan"

Pasal 47 ayat (1) POJK menyatakan:m Atas pelanggaran kewajiban dan larangan dalam peraturan OJK ini, OJK berwenang mengenakan sanksi administratif terhadap Penyelenggara berupa: a. peringatan tertulis; b. denda, yaitu kewajiban untuk membayar sejumlah uang tertentu; c. pembatasan kegiatan usaha; dan d. pencabutan izin.

\section{Analisis Konsekuensi Hukum Pidana dalam terjadinya tindakan penagihan yang bersifat intimidatif oleh perusahaan P2P Lending.}

Tindakan penagihan utang merupakan hal yang wajar dilakukan oleh pemberi pinjaman, dalam hal terjadinya keterlambatan pembayaran. Teknis penagihan utang juga merupakan hal yang biasanya telah disepakati oleh para pihak di dalam perjanjian. Dalam transaksi peminjaman dana melalui aplikasi online, banyak terjadi kasus kredit macet. Terdapat berbagai faktor penyebab terjadinya gagal bayar, misalnya karena dana belum tersedia pada debitur, namun debitur sebenarnya memiliki iktikad baik untuk membayar, sehingga yang terjadi hanya kasus keterlambatan pembayaran.

Selain itu, terdapat pula kasus di mana debitur memang sengaja dan tanpa itikad baik tidak melakukan pembayaran. Hal seperti ini tentunya merugikan pihak pemberi pinjaman. Teknis penagihan utang oleh perusahaan P2P Lending memang belum diatur secara spesifik di dalam peraturan OJK. 
Dalam kenyataannya, dalam proses penagihan, pihak perusahaan P2P Lending melakukan beberapa tindakan melawan hukum di antaranya:

a. Ancaman terus menerus melalui telepon

b. Penagihan utang dilakukan dengan menghubungi keluarga, kerabat, teman hingga atasan tempat bekerja. Dengan cara mengakses kontak data dalam handphone nasabah secara ilegal

c. Membuat grup Whatsapp yang berisi keluarga, kerabat, teman, hingga atasan kerja nasabah

d. Penagihan utang dilakukan dengan menyebarkan foto debitur ke dalam grup whatsapp yang dibuatnya tersebut

e. Mengintimidasi dengan kata-kata kasar caci maki dan berbau pelecehan seksual

Apabila penagihan yang dilakukan melalui sms atau jenis pesan elektronik lainnya, dan di dalam pesan tersebut terdapat unsur pengancaman, maka tindakan tersebut dapat dikenakan sanksi menurut UU ITE sebagai berikut:

Pasal 29 Setiap Orang dengan sengaja dan tanpa hak mengirimkan Informasi Elektronik dan/atau Dokumen Elektronik yang berisi ancaman kekerasan atau menakut-nakuti yang ditujukan secara pribadi

Pasal 45 B: Setiap Orang yang dengan sengaja dan tanpa hak mengirimkan Informasi Elektronik dan/atau Dokumen Elektronik yang berisi ancaman kekerasan atau menakut-nakuti yang ditujukan secara pribadi sebagaimana dimaksud dalam Pasal 29 dipidana dengan pidana penjara paling lama 4 (empat) tahun dan/atau denda paling banyak Rp750.000.000,00 (tujuh ratus lima puluh juta rupiah).

Jika Perusahaan P2P Lending, melalui pegawainya, membuat grup dalam aplikasi percakapan, mengundang orang-orang yang berada pada daftar kontak debitur untuk bergabung dalam grup, dan pada grup tersebut disebarkan informasi mengenai kasus debitur tidak membayar utang, maka dapat dikenakan beberapa pasal pidana di bawah ini:

Pasal 27 ayat (3): Setiap Orang dengan sengaja dan tanpa hak mendistribusikan dan/atau mentransmisikan dan/atau membuat dapat diaksesnya Informasi Elektronik dan/atau Dokumen Elektronik yang memiliki muatan penghinaan dan/atau pencemaran nama baik.

Pasal 45 (3) Setiap Orang yang dengan sengaja dan tanpa hak mendistribusikan dan/atau mentransmisikan dan/atau membuat dapat diaksesnya Informasi Elektronik dan/atau Dokumen Elektronik yang memiliki muatan penghinaan dan/atau pencemaran nama baik sebagaimana dimaksud dalam Pasal 27 ayat (3) dipidana dengan pidana penjara paling lama 4 (empat) tahun dan/atau denda paling banyak Rp750.000.000,00 (tujuh ratus lima puluh juta rupiah). 
Di dalam UU ITE juga diberikan definisi bahwa yang dimaksud dengan "orang" pada rumusan pasal-pasal dalam UU ITE, termasuk pengertian badan hukum. Dengan demikian, perusahaan P2P Lending yang melakukan akses daftar kontak milik debitur dan kemudian menggunakannya untuk kepentingan penagihan secara intimidatif, dapat dipertanggungjawabkan secara pidana. Hal ini berarti, pihak directing mind atau penanggungjawab korporasi tersebut dapat dikenai sanksi pidana. Namun sejauh ini, perusahaan $P 2 P$ Lending yang melakukan tindakan-tindakan tersebut belum dikenai sanksi pidana.

\section{Penutup}

\section{Kesimpulan}

Berdasarkan pemaparan yang telah dilakukan, dapat disimpulkan bahwa:

1. Klausul yang menetapkan bahwa debitur menyetujui tindakan akses kontak oleh perusahaan P2P Lending merupakan salah satu bentuk penyalahgunaan keadaan (undue influence). Di Indonesia, syarat keabsahan suatu kontrak adalah dipenuhinya Pasal 1320 KUH Perdata, yaitu syarat kesepakatan, kecakapan, adanya suatu hal tertentu, dan adanya kausa yang halal. Suatu kesepakatan tidak boleh disertai adanya paksaan, kekhilafan dan / atau penipuan. Ajaran penyalahgunaan keadaan adalah menyangkut perwujudan asas kebebasan berkontrak, karena hal itu menyangkut penyalahgunaan untuk mengganggu adanya kebebasan kehendak untuk mengadakan persetujuannya. Untuk melindungi debitur dan pihak ketiga dari tindakan intimidatif, negara harus menegakan hukum pidana atas tindakan tersebut.

2. Penegakan hukum pidana atas tindakan penagihan secara intimidatif dapat dilakukan berdasarkan berlakunya Pasal 29 jo.Pasal 45 UU ITE dan Pasal 27 ayat (3) jo. Pasal 45 ayat (3) UU ITE,

\section{Saran}

1. Diperlukan kerjasama antara OJK dan Kementrian Komunikasi dan Informatika, untuk mengawasi pemberlakuan klausula terkait akses data kontak. OJK menjalankan fungsi di bidang pengawasan aspek perlindungan konsumen, Kominfo melakukan tindakan pemblokiran konten dan sejenisnya,

2. Perusahaan P2P Lending menyesuaikan klausul terkait dengan akses daftar kontak debitur. Akses daftar kontak hanya akan dilakukan sebatas untuk tujuan verifikasi data debitur sebelum pinjaman disetujui.

3. Konsumen agar lebih berhati-hati dalam mengijinkan sebuah aplikasi untuk dapat melakukan akses daftar kontak. 


\section{Daftar Pustaka}

\section{Buku:}

Agus Yudha Hernoko, 2009, Hukum Perjanjian Asas Proporsionalitas Dalam Kontrak Komersial, Jakarta: Kencana Prenadamedia Group.

Hardijan Rusli, Hukum Perjanjian Indonesia dan Common Law, Jakarta, Pustaka Sinar Harapan, 1996

Johnny Ibrahim.Teori dan Metodologi Penelitian Hukum Normatif. Malang: Bayumedia Publishing, 2006

Ronny Hanitijo Soemitro, Metodologi Penelitian Hukum, Jakarta:Ghalia Indonesia,1982

Soenaryo, Metode Riset I, Surakarta: Universitas Sebelas Maret, 1985

Sukarmi, Cyber Law: Kontrak Elektronik dalam Bayang-Bayang Pelaku Usaha, Bandung, Pustaka Sutra, (2008)

\section{Perundang-undangan:}

Kitab undang-undang Hukum Perdata

Undang-undang Nomor 8 tahun 1999 tentang Perlindungan Konsumen

Undang-undang Nomor 11 tahun 2008 sebagaimana diubah dengan Undang-undang Nomor 19 tahun 2016 tentang Informasi dan Transaksi Elektronik

Peraturan Otoritas Jasa Keuangan Nomor 77 /POJK.01/2016 tentang Layanan Pinjam Meminjam Uang Berbasis Teknologi Informasi

\section{Jurnal Ilmiah:}

Erna Priliasari, Pentingnya Perlindungan Data Pribadi Dalam Transaksi Pinjaman Online (The Urgency Of Personal Protection In Peer To Peer Lending), Majalah Hukum Nasional, Nomor 2 tahun 2019.

Fatmah Paparang, Misbruik Van Omstandigheden Dalam Perkembangan Hukum Kontrak , Jurnal Hukum Unsrat, Vol.22/No.6/Juli /2016

Istiqamah, Analisis Pinjaman Online Oleh Fintech Dalam Kajian Hukum Perdata, Jurisprudentie, Jurnal Hukum UIN Allaudin, Volume 6 Nomor 2 Desember 2019 
Lina Jamilah, Asas kebebasan Berkontrak Dalam Perjanjian Standar Baku, Syiar Hukum Vol 14, No.1, (2012)

\section{Pranala Luar:}

https://www.ojk.go.id/id/berita-dan-kegiatan/siaran-pers/Pages/Satgas-Waspada-Investasi-

Temukan-lagi-125-Fintech-Peer-To-Peer-Lending-Ilegal.aspx diakses tanggal 20 Februari 2020, pukul 13.00 WIB.

www.uangteman.com, diakses tanggal 21 Februari 2020, pukul 10.00 WIB.

https://www.cermati.com/artikel/cara-lapor-polisi-bila-diteror-dan-diancam-pinjaman-online, diakses tanggal 21 Februari 2020, pukul 10.00 WIB 